\title{
Pengaruh Tingkat Pendidikan, Pengalaman Kerja dan Gaya Kepemimpinan pada Efektivitas SPI Bank X Denpasar
}

\author{
Gintar Gimbara ${ }^{1}$ \\ Fakultas Ekonomi dan Bisnis \\ Universitas Udayana, Indonesia
}

\author{
I Wayan Ramantha ${ }^{2}$ \\ Fakultas Ekonomi dan Bisnis \\ Universitas Udayana, Indonesia
}

\begin{abstract}
Surel : gintar.gimbara@gmail.com
ABSTRAK

Tujuan penelitian ini adalah untuk mengetahui pengaruh tingkat pendidikan, pengalaman kerja dan gaya kepemimpinan terhadap efektivitas sistem pengendalian internal. Penelitian ini dilakukan di Bank X Kota Denpasar. Jumlah sampel yang diambil sebanyak 35 orang pegawai, dengan teknik sample jenuh. Pengumpulan data dilakukan dengan penyebaran kuisioner. Teknik analisa digunakan adalah regresi linear berganda. Hasil penelitian ini menunjukan bahwa tingkat pendidikan, pengalaman kerja dan gaya kepemimpinan secara parsial berpengaruh positif terhadap efektivitas sistem pengendalian internal Bank $X$ Denpasar. Pengawas sistem pengendalian internal penting untuk memiliki tingkat pendidikan yang tinggi guna meningkatkan kemampuan dalam melakukan pengawasan sebagai upaya meningkatkan efektivitas sistem pengendalian internal.
\end{abstract}

Kata Kunci: Tingkat Pendidikan; Pengalaman Kerja; Gaya Kepemimpinan; Efektivitas Sistem Pengendalian Internal.

Effects of Education Level, Work Experience and Leadership Style on the Effectiveness of Internal Control System in X Bank Denpasar

\section{ABSTRACT}

The purpose of this study was to determine the effect of education level, work experience and leadership style on the effectiveness of the internal control system. This research was conducted at Bank X Denpasar City. The number of samples taken was 35 employees, with saturated sample technique. Data collection is done by distributing questionnaires. The analysis technique used is multiple linear regression. The results of this study indicate that the level of education, work experience and leadership style partially have a positive effect on the effectiveness of the Bank X Denpasar internal control system. Supervision of the internal control system is important to have a high level of education in order to increase the ability to conduct supervision in an effort to increase the effectiveness of the internal control system.

Keywords: $\quad$ Level of education; Work experience; Leadership Style; Effectiveness of the Internal Control System.

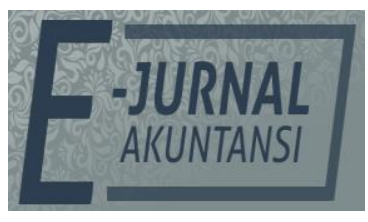

e-ISSN 2302-8556

Vol. 30 No. 8

Denpasar, Agustus 2020 Hal. 2065-2077

DOI:

10.24843/EJA.2020.v30.i08.p13

PENGUTIPAN:

Gimbara, G. \& Ramantha, I W. (2020). Pengaruh Tingkat Pendidikan, Pengalaman Kerja dan Gaya

Kepemimpinan pada Efektivitas SPI Bank X

Denpasar. E-Jurnal Akuntansi, 30(8), 2065-2077

RIWAYAT ARTIKEL: Artikel Masuk: 13 Maret 2020 Artikel Diterima: 13 Juli 2020

Artikel dapat diakses : https://ojs.unud.ac.id/index.php/Akuntansi/index 


\section{PENDAHULUAN}

Adanya Sistem Pengendalian Internal di suatu perusahaan sangat penting untuk menunjang perbaikan pengelolaan sistem dan menjadi faktor yang mendukung terciptanya tata kelola yang akuntabel dan juga transparan sebagai bukti bahwa kinerja yang sudah dilaksanakan berjalan dengan sistem yang baik sehingga akan berdampak baik bagi perusahaan itu sendiri (Azzali \& Mazza, 2018). Sistem Pengendalian Internal didefinisikan sebagai tindakan yang dilakukan pada keuangan dan non-keuangan untuk memastikan perlindungan aset, deteksi dan pencegahan penipuan, memenuhi persyaratan dan prosedur kebijakan internal kontrol dan akurasi kelengkapan catatan (Abiola, 2013). Banyak faktor yang dapat mempengaruhi keberhasilan dari pengendalian internal sistem akuntansi disuatu perusahaan yaitu salah satunya tingkat pendidikan, pengalaman kerja dan juga gaya kepemimpinan dari sumber daya manusianya yang menjadi penggerak dari sistem itu sendiri (Salehi, 2016). Sistem pengendalian internal merupakan suatu cara untuk mengawasi dan mengukur suatu daya organisasi serta berperan penting dalam pencegahan dan pendeteksian pengelapan. Adanya sistem pengendalian internal yang baik diharapkan dapat meningkatkan keandalan data akuntansi yang dihasilkan (Warren et al., 2005:21).

Penelitian ini dilakukan pada Bank X Denpasar, Provinsi Bali. Bank ini melayani nasabah untuk membuat atau membuka rekening baru, penyetoran simpanan dana tunai, penarikan dana, pengajuan pinjaman Bank $X$, pengajuan kredit, cek saldo dan produk-produk lainnya dari Bank X. Pelaksanakan Sistem pengendalian Internal Bank $X$ berpedoman pada Surat Edaran Otoritas Jasa Keuangan Nomor 36/SEOJK/2017 tanggal 7 Juli 2017 Tentang Pedoman Standar Sistem Pengendalian Internal Bagi Bank Umum. Sistem Pengendalian Intern pada Bank X disebut sebagai suatu mekanisme yang telah ditetapkan oleh Bank X itu sendiri secara berkesinambungan, karena memiliki tujuan yang jelas yaitu untuk menjaga dan mengamankan harta kekayaan, menjamin dapat menyediakan data yang akurat serta tepat waktu dalam menyelesaikannya, meningkatkan kepatuhan terhadap berbagai bentuk peraturan yang berlaku saat ini. Penyelenggaraan sistem pengendalian Intern Bank $X$ yang handal dan efektif masih harus selalu melakukan kegiatan evaluasi terkait dengan berjalannya kegiatan pengawasan tersebut karena tidak jarang ditemukan hal-hal yang dapat mempengaruhi efektivitas dari pengawasan intern tersebut. Pelaksanaan evaluasi tersebut berkaitan dengan adanya perubahan kondisi intern dan ekstern, serta kapasitas dari sistem pengendalian tersebut harus selalu diperhatikan agar efektivitasnya dapat ditingkatkan (Tunji, 2013).

Pengawasan internal bagi suatu perusahaan sangat diperlukan agar dapat berjalan sesuai rencana dan terlaksana dengan efektivitas waktu yang lebih baik (Zahara \& Silviana, 2015). Satuan Pengawas Internal merupakan unit kerja yang membantu dan memiliki tanggungjawab terhadap Pimpinan Instansi dalam mengawasi dan mengevaluasi Sistem Pengendalian Internal sehingga jalannya suatu Instansi dapat mengarah dalam jalur yang benar sesuai dengan rencana (Afifah \& Azwari, 2015). Satuan Pengawas Internal diharapkan memiliki independensi yang tinggi, artinya seseorang yang membidangi bagian tersebut mampu memiliki sikap yang bebas dari hambatan, memberi opini yang objektif, tidak dibatasi, dan melaporkan masalah yang terjadi dengan sebenar-benarnya, 
tidak memihak salah satu pihak, mampu bersikap adil dan bukan berdasarkan keinginan eksekutif atau perusahaan itu sendiri.

Efektivitas sistem pengendalian internal dari suatu perusahaan dapat terlaksana dengan baik juga didukung dengan kualitas dari Sumber Daya Manusianya yang bertugas sebagai penggerak dari sistem akuntansi khususnya yang ada di dalam perusahaan tersebut. Pengawasan ekstra tidak menjamin sistem tersebut akan berjalan dengan efektif sesuai dengan rencana apabila tidak didukung oleh tenaga kerja yang memiliki kompetensi dan kemampuan yang sesuai dengan bidangnya. Tingkat Pendidikan dari seorang pegawai disuatu perusahaan sangat perlu diperhatikan, karena secara tidak langsung hal tersebut sangat mempengaruhi hasil yang ingin dicapai dari suatu perusahaan, karena apabila sistem didalamnya sudah baik, maka perusahaan tersebut juga akan berjalan dengan baik. Pernyataan ini sejalan dengan penelitian yang dilakukan Akadita (2010) yang menyatakan bahwa pengawas internal diukur melalui tingkat pendidikan terakhir yang dimiliki oleh seorang pengawas, semakin tinggi tingkat Pendidikan seorang pegawai maka ilmu atau kemampuan yang mereka miliki akan memudahkan dalam melakukan kegiatan pengawasan yang lebih efektif. Pernyataan ini sejalan dengan penelitian Bhuaneswari \& Damayanthi (2018) yang menyatakan tingkat pendidikan berpengaruh positif dan signifikan pada efektivitas sistem pengendalian internal.

Kualitas dari pengendalian internal dalam suatu perusahaan dapat pula dilihat dari pengalaman kerja yang dimiliki, seorang pekerja cenderung akan lebih menguasai pekerjaan dengan mudah apabila didukung dengan pengalaman kerja yang cukup. Dengan masa kerja yang cukup akan memudahkan seseorang untuk menguasai pekerjaan tersebut dan membantu efektivitas dalam melakukan pengawasan internal (Jones, 2008). Pengalaman kerja yang dimiliki seseorang menunjukkan kemampuan dan juga pengetahuan terkait dengan pekerjaan yang akan dibidangi akan memberikan peluang besar bagi seseorang untuk melakukan pekerjaan yang lebih baik (Irafah et al., 2019). Auditor yang berpengalaman cenderung tidak melakukan kesalahan yang besar dibandingkan dengan yang tidak berpengalaman (Apsari \& Gayatri, 2018). Hal tersebut dapat mengurangi terjadinya kesalahan-kesalahan yang mungkin dapat terjadi. Hal lain yang perlu diperhatikan adalah gaya kepemimpinan dari seorang pegawai yang dalam hal ini bertugas sebagai pengawas internal dari suatu perusahaan. Pernyataan ini sejalan dengan penelitian yang dilakukan Ekayanti et al. (2017) yang menyatakan bahwa pengalaman kerja berpengaruh positif pada efektivitas sistem pengendalian internal. Perilaku atau gaya kepemimpinan mencerminkan bagaimana seseorang dapat melakukan tugas dengan baik karena akan berpengaruh kepada sikap dari pegawai lainnya sehingga berdampak kepada efektivitas pengendalian internal perusahaan itu sendiri (Indriasih \& Koeswayo, 2014). Peneliti menambahkan variabel gaya kepemimpinan karena gaya kepemimpianan dari seorang ataasan kepada pegawainya akan berdampak terhadap efektivitas sistem pengendalian internal (Wicaksono, 2013). Gaya kepemimpinan yang buruk akan mempengaruhi kepuasan kinerja pegawai, sehingga menyebabkan pegawai cenderung merugikan perusahaannya, Sedangkan gaya kepemimpinan yang baik akan meningkatkan efektivitas sistem pengendalian internal. Hal ini sejalan dengan penelitian Kibtiyah et al. (2017) yang 
menyatakan gaya kepemimpinan berpengaruh positif terhadap efektivitas sistem pengendalian internal.

Pendidikan adalah proses pembelajaran untuk mengembangkan kemampuan, meningkatkan ilmu pengetahuan dan mengubah perilaku pada manusia (Wambarika \& Ramantha, 2017). Pendidikan diperoleh melalui pembelajaran secara terstruktur dalam waktu yang relatif lama. Tingkat pendidikan adalah suatu tahapan pendidikan dari pendidikan dasar, pendidikan menengah sampai pendidikan tinggi dalam proses pembelajaran untuk tujuan yang akan dicapai. Seorang pengawas internal yang memiliki tingkat pendidikan yang sesuai dengan fungsi pengawas akan memahami elemen-elemen dari pengendalian internal sehingga efektivitas pengendalian internal akan meningkat (Mulihartini \& Muliartha, 2016).

Penelitian Bhuaneswari \& Damayanthi (2018) menyatakan bahwa tingkat pendidikan berpengaruh positif terhadap efektivitas pengendalian internal LPD di Kota Denpasar, hal ini karena seorang pengawas internal yang memiliki tingkat pendidikan yang sesuai dengan fungsi pengawasan internal akan lebih memahami suatu prosedur maupun kebijakan yang menunjang pengendalian internal LPD dimana kebijakan yang ada telah dilaksanakan dengan baik sehingga efektivitas sistem pengendalian internal LPD tersebut meningkat. Penelitian lain yang dilakukan Mirawati (2014) menyatakan bahwa tingkat pendidikan pegawai perusahaan tekstil berpengaruh positif terhadap efektivitas sistem pengendalian internal. Berdasarkan uraian tersebut dapat dirumuskan hipotesis sebagai berikut: $\mathrm{H}_{1}$ : Tingkat pendidikan berpengaruh positif pada efektivitas sistem pengendalian internal Bank X Denpasar.

Pengalaman kerja adalah pengetahuan atau keterampilan yang telah diketahui dan dikuasai seseorang akibat dari perbuatan atau pekerjaan yang telah dilakukan selama beberapa waktu yang lalu (Trijoko, 1980). Pengalaman kerja seseorang menunjukan jenis-jenis pekerjaan yang telah dilakukan seseorang dan memberikan peluang besar bagi seseorang untuk melakukan pekerjaan yang lebih baik. Menurut penelitian yang dilakukan Wijaya et al. (2016) menyatakan pengalaman kerja berpengaruh positif terhadap efektivitas penerapan sistem pengendalian internal pada auditor internal yang bertugas di perusahaan pembiayaan se Kabupaten Kudus.

Penelitian Dianawati \& Ramantha (2013) menyatakan bahwa pengalaman kerja auditor internal berpengaruh positif terhadap efektivitas sistem pengendalian internal. Hal ini karena pengalaman kerja auditor internal merupakan suatu proses pembelajaran dan pertambahan potensi bertingkah laku baik dari pendidikan formal maupun pendidikan non formal atau bisa diartikan sebagai suatu proses yang membawa seseorang kepada suatu pola tingkah yang lebih tinggi. Berdasarkan uraian tersebut dapat dirumuskan hipotesis sebagai berikut:

$\mathrm{H}_{2}$ : Pengalaman kerja berpengaruh positif pada efektivitas sistem pengendalian internal Bank X Denpasar.

Gaya kepemimpinan adalah suatu proses untuk mempengaruhi sekelompok orang yang mau bekerja dengan sungguh-sungguh untuk meraih tujuan kelompok. Berkaitan dengan gaya kepemimpinan, penelitian yang dilakukan Kibtiyah et al. (2017) menemukan bahwa gaya kepemimpinan seorang 
pemimpin dianggap mempunyai peranan pada kinerja penjabat pengadaan. Penelitian ini sejalan dengan penelitian Schaefer \& Savulescu (2014) yang menyatakan bahwa pemimpin mempunyai peran yang cukup besar dalam memantau pelaksanaan kegiatan dalam suatu organisasi dan efektivitas sistem pengendalian internal dapat menjadi lemah ketika terjadi inkonsistensi dalam melakukan bimbingan oleh seorang pemimpin.

Gaya kepemimpinan mempengaruhi kinerja Satuan Pengawas Internal, sebab salah satu hal yang dapat memengaruhi efektivitas sistem pengendalian internal adalah adanya pemantauan yang cukup oleh pimpinan instansi terkait.:

$\mathrm{H}_{3}$ : Gaya kepemimpinan berpengaruh positif pada efektivitas sistem pengendalian internal Bank X Denpasar.

\section{METODE PENELITIAN}

Penelitian ini dilakukan pada pegawai atau karyawan di Bank $X$ Cabang Denpasar, yang berada di Kompleks Pertokoan Titi Mandala No. 1, Jalan Raya Puputan, Renon, Denpasar, Dangin Puri Klod, Kec. Denpasar Timur, Kota Denpasar, Bali. Alasan yang mendasari dipilihnya lokasi ini karena memiliki akses atau orang dalam untuk mengetahui efektivitas sistem pengendalian internal pada Bank X Denpasar. Objek dari penelitian ini adalah pegawai atau karyawan yang terlibat dalam mempengaruhi penerapan efektivitas sistem pengendalian internal pada Bank X Denpasar.

Tingkat pendidikan adalah jenjang pendidikan pegawai yang diukur dengan tingkat atau strata pendidikan mulai dari SMA sampai dengan pasca sarjana (S3) yang dimiliki oleh pegawai (Wardani, 2014). Adapun variabel tingkat pendidikan akan diukur dengan 7 (tujuh) pernyataan yang diadopsi dari kuesioner (Wardani, 2014). Indikator kuesioner dari tingkat pemdidikan adalah latar belakang pendidikan, strata pendidikan, dan pendidikan dilakukan secara periodik. Pengalaman kerja adalah suatu ukuran pengetahuan, keterampilan, dan pemahaman yang telah diketahui dan dikuasai oleh seseorang dalam melakukan tugas-tugas maupun pekerjaan dalam bidang tertentu dan jangka waktu tertentu secara intensif yang menghasilkan kompetensi dan mampu mengatasi permasalahan dengan baik. Adapun variabel pengalaman kerja akan diukur dengan 10 (sepuluh) pernyataan yang diadopsi dari kuesioner (Wardani, 2014). Indikator dari kuesioner dari pengalaman kerja adalah jangka waktu bekerja, bidang pengalaman kerja, dan manfaat pengalaman kerja pegawai atau karyawan bank pada dibidang masing-masing.

Gaya kepemimpinan adalah kemampuan seorang pemimpin dalam mempengaruhi pegawainya sehingga mereka akan berusaha dan berkomitmen tehadap tujuan organisasi tersebut. Adapun variabel gaya kepemimpinan akan diukur dengan 6 (enam) pernyataan yang diadopsi dari kuesioner (Wicaksono, 2013). Indikator kuesioner gaya kepemimpinan adalah relasi pimpinan dengan pegawai bank, struktur tugas dan posisi kekuatan.

Sistem pengendalian internal adalah suatu cara untuk mengarahkan, mengawasi dan mengukur suatu sumber daya organisasi atau perusahaan serta berperan penting dalam pencegahan dan pendeteksian. Jadi efektivitas sistem pengendalian internal merupakan suatu kemampuan sistem pengendalian internal yang telah dibuat, dievaluasi dan ditetapkan dari waktu ke waktu dalam 
mencapai tujuan pelaporan keuangan, pengamanan aset negara, dan ketaatan terhadap peraturan undang-undang. Adapun variabel efektivitas sistem pengendalian internal akan diukur dengan 9 (sembilan) pernyataan yang diadopsi dari kuesioner (Soimah, 2014). Indikator kuesioner dari efektivitas sistem pengendalian internal adalah lingkungan pengendalian, penilaian resiko, kegiatan pengendalian, informasi dan komunikasi, serta pemantauan.

Populasi yang digunakan dalam penelitian ini adalah seluruh pegawai atau karyawan yang terkait dengan sistem pengawasan internal pada Bank $X$ Denpasar. Metode pengambilan sampel yang digunakan di dalam penelitian ini yakni dengan menggunakan nonprobability sampling dengan teknik sampel jenuh. Sampel jenuh adalah seluruh anggota populasi dijadikan sampel dalam penelitian.

Analisis regresi linear berganda digunakan untuk mengetahui atau memperoleh gambaran mengenai pengaruh Tingkat Pendidikan $\left(X_{1}\right)$, Pengalaman Kerja $\left(X_{2}\right)$ dan Gaya Kepemimpinan $\left(X_{3}\right)$ pada Efektivitas Sistem Pengendalian Internal $(Y)$. Analisis dilakukan dengan menggunakan program SPSS. Model regresi linear berganda dalam penelitian ini ditunjukan dengan persamaan berikut.

$$
\begin{aligned}
& Y=\alpha+\beta_{1} X_{1}+\beta_{2} X_{2}+\beta_{3} X_{3} \varepsilon \ldots \ldots \ldots \ldots \ldots \ldots \\
& \text { Keterangan: } \\
& Y=\text { Efektivitas Sistem Pengendalian Internal } \\
& \alpha=\text { Konstanta } \\
& \beta_{1}=\text { koefisien regresi tingkat pendidikan } \\
& \beta_{2}=\text { koefisien regresi pengalaman kerja } \\
& \beta_{3}=\text { koefisien regresi gaya kepemimpinan } \\
& X_{1}=\text { tingkat pendidikan } \\
& X_{2}=\text { pengalaman kerja } \\
& X_{3}=\text { gaya kepemimpinan } \\
& \varepsilon=\text { tingkat kesalahan atau tingkat gangguan }
\end{aligned}
$$

\begin{tabular}{|c|c|c|c|c|c|}
\hline Variabel & $N$ & Minimum & Maximum & Mean & Std. Deviation \\
\hline Tingkat Pendidikan (X1) & 35 & 21 & 35 & 30,00 & 3,750 \\
\hline Pengalaman Kerja (X2) & 35 & 37 & 50 & 43,20 & 3,018 \\
\hline Gaya Kepemimipinan (X3) & 35 & 22 & 30 & 26,11 & 2,298 \\
\hline $\begin{array}{l}\text { Efektivitas } \\
\text { Pengendalian }\end{array}$ & 35 & 35 & 45 & 39,43 & 2,943 \\
\hline
\end{tabular}

\section{HASIL DAN PEMBAHASAN}

Statistik dalam penelitian ini disajikan untuk memberikan informasi mengenai karakteristik variabel-variabel penelitian, antara lain minimum, maksimum, mean dan standar deviasi. Hasil statistik deskriptif dapat dilihat pada Tabel 1 sebagai berikut.

Tabel 1. Hasil Statistik Deskriptif 
Berikut adalah tabel mengenai tentang rentang klasifikasi masing-masing variabel yang digunakan dalam penelitian ini, Tabel 2, digunakan untuk mengetahui klasifikasi masing-masing variabel berdasarkan nilai mean yang terdapat pada Tabel 1.

Tabel 2. Klafisikasi Varibel Penelitian

\begin{tabular}{lcccc}
\hline \multicolumn{1}{c}{ Rentang } & $\begin{array}{c}\text { Tingkat } \\
\text { Pendidikan }\end{array}$ & $\begin{array}{c}\text { Pengalaman } \\
\text { Kerja }\end{array}$ & $\begin{array}{c}\text { Gaya } \\
\text { Kepemimpinan }\end{array}$ & $\begin{array}{c}\text { Efektivitas } \\
\text { SPI }\end{array}$ \\
\hline $10,0 \leq \mathrm{x}<10,8$ & Sangat & Sangat & Sangat & Sangat \\
& Rendah & Rendah & Rendah & Rendah \\
$10,81 \leq \mathrm{x}<20$, & Rendah & Rendah & Rendah & Rendah \\
$20,61 \leq x<25,4$ & Sedang & Sedang & Sedang & Sedang \\
$25,41 \leq x<30,2$ & Tinggi & Tinggi & Tinggi & Tinggi \\
& Sangat & Sangat & & Sangat \\
$30,21 \leq x<50,0$ & Tinggi & Tinggi & Sangat Tinggi & Tinggi \\
\hline
\end{tabular}

Sumber: Data Penelitian, 2020

Berdasarkan Tabel 1, dapat dilihat mengenai nilai minimum untuk tingkat pendidikan adalah 21 sedangkan nilai maksimumnya adalah 35. Mean untuk tingkat pendidikan adalah 30,00 dengan standar deviasinya 3,750. Berdasarkan Tabel 2, mean tingkat pendidikan termasuk pada klasifikasi tinggi, hal ini berarti dari 35 responden yang diteliti, secara umum persepsi responden setuju terhadap beberapa pernyataan variabel tingkat pendidikan. Standar deviasi 3,750 berarti terjadi penyimpangan tingkat pendidikan terhadap nilai rata-rata yaitu sebesar 3,750 .

Variabel pengalaman kerja nilai minimumnya adalah 37 sedangkan nilai maksimumnya adalah 50. Mean untuk pengalaman kerja adalah 43,20 . Sedangkan standar deviasinya sebesar 3,018. Berdasarkan Tabel 2, mean pengalaman kerja termasuk pada klasifikasi tinggi, berarti dari 35 responden yang diteliti, secara umum persepsi responden setuju terhadap beberapa pernyataan variabel pengalaman kerja. Standar deviasinya 3,018 hal ini berarti terjadi penyimpangan nilai pengalaman kerja terhadap nilai rata-ratanya sebesar 3,018.

Variabel gaya kepemimpinan nilai minimumnya adalah 22, nilai maksimumnya gaya kepemimpinan adalah 30 . Mean variabel gaya kepemimpinan adalah 26,11. Sedangkan standar deviasinya gaya kepemimpinan sebesar 2,298. Berdasarkan Tabel 2, mean gaya kepemimpinan termasuk pada klasifikasi tinggi, hal ini berarti dari 35 responden yang diteliti, secara umum persepsi responden setuju terhadap beberapa pernyataan variable gaya kepemimpinan. Standar deviasinya 2,298 hal ini berarti terjadi penyimpangan gaya kepimpinan terhadap nilai rata-ratanya sebesar 2,298.

Untuk variabel efektifitas sistem pengendalian internal nilai minimumnya 35 dan nilai maksimumnya 45. Mean variabel efektivitas sistem pengendalian internal adalah 39,43. Sedangkan standar deviasinya sebesar 2,943. Berdasarkan Tabel 2, mean efektifitas sistem pengendalian internal termasuk pada klasifikasi tinggi, hal ini berari dari 35 responden yang diteliti, secara umum persepsi responden setuju terhadap beberapa pernyataan pada variabel efektivitas sistem pengendalian internal. Standar deviasi 2,943 berarti terjadi penyimpangan efektivitas sistem pengendalian internal terhadap nilai rata-rata sebesar 2,943. 
Analisis regresi linear berganda digunakan untuk mengetahui pengaruh dari variabel bebas terhadap variabel terikat atas perubahan dari setiap peningkatan atau penurunan variabel bebas yang akan mempengaruhi variabel terikatnya.

Tabel 3. Hasil Analisis Regresi Linier Berganda

\begin{tabular}{llll}
\hline \multirow{2}{*}{ No } & \multirow{2}{*}{ Variabel } & \multicolumn{2}{c}{ Unstandarized Coeffisients } \\
& & $\mathrm{B}$ & Std.Error \\
\hline \multirow{2}{*}{1} & (Constant) & $-13,925$ & 6,926 \\
2 & Tingkat Pendidikan (X1) & 0,149 & 0,129 \\
3 & Pengalaman Kerja (X2) & 0,101 & 0,147 \\
\hline
\end{tabular}

Sumber: Data Penelitian, 2020

Berdasarkan Tabel 3, analisis regresi berganda, maka dapat dibuat suatu persamaan regresi sebagai berikut.

$$
\mathrm{Y}=-13,925+0,149 \mathrm{X} 1+0,101 \times 2+0,638 \times 3
$$

Persamaan regresi menunjukan nilai konstanta sebesar - 13,925. Hal ini berarti jika variabel tingkat pendidikan $\left(X_{1}\right)$, pengalaman kerja $\left(X_{2}\right)$, gaya kepemimpinan $\left(X_{3}\right)$ nilainya adalah 0 , maka efektivitas sistem pengendalian internal (Y) akan memiliki nilai negatif, maka nilainya sebesar $-13,925$.

Koefisien variabel tingkat pendidikan $\left(\mathrm{X}_{1}\right)$ sebesar 0,149 , hal ini berarti jika variabel tingkat pendidikan bertambah satu satuan, maka variabel efektivitas sistem pengendalian bertambah sebesar 0,149 dengan asumsi variabel lainnya konstan.

Koefisien variabel pengalaman kerja $\left(\mathrm{X}_{2}\right)$ sebesar 0,101, hal ini berarti jika variabel pengalaman kerja bertambah satu satuan, maka variabel efektivitas sistem pengendalian internal bertambah sebesar 0,101 dengan asumsi variabel lainnya konstan.

Koefisien variabel gaya kepemimpinan $\left(X_{3}\right)$ sebesar 0,638 , hal ini berarti jika variabel gaya kepemimpinan bertambah satu satuan, maka variabel efektivitas sistem pengendalian internal bertambah sebesar 0,638 dengan asumsi variabel lainnya konstan.

Nilai $\varepsilon$ (Error) dalam konsep statistika khususnya di dalam konsep regresi linear, Error adalah semua hal yang mungkin mempengaruhi variabel terikat $(\mathrm{Y})$ yang mungkin tidak diamati oleh peneliti.

Uji $R^{2}$ pada regresi linear diartikan sebagai kemampuan semua variabel bebas dalam menjelaskan variance dari variabel terikatnya. Hal ini $\mathrm{R}^{2}$ dapat dilihat pada Tabel 4, sebagai berikut:

Tabel 4. Hasil Uji Koefisien Determinasi

\begin{tabular}{lll}
\hline No & Keterangan & Nilai \\
\hline 1 & $\mathrm{R}$ & 0,639 \\
2 & $\mathrm{R}^{2}$ & 0,409 \\
3 & Adjusted $\mathrm{R}^{2}$ & 0,352 \\
\hline
\end{tabular}

Sumber: Data Penelitian, 2020

Berdasarkan Tabel 4, diperoleh nilai kofisien korelasi berganda (R) sebesar 0,639. Hal ini menunjukan bahwa variabel tingkat pendidikan, pengalaman kerja dan gaya kepemimpinan pada efektivitas sistem pengendalian internal mempunyai hubungan yang sangat kuat. Hal ini pada Tabel 4, juga 
menunjukan bahwa nilai koefisien determinasi ( $\mathrm{R}$ square) sebesar 0,409 dan koefisien determinasi yang disesuaikan (Adjusted $\mathrm{R}$ square) adalah 0,352. Nilai adjusted $R$ square sebesar 0,352, hal ini berarti sebesar 35,2 (\%) variabel tingkat pendidikan, pengalaman kerja dan gaya kepemimpinan pada efektivitas sistem pengendalian internal, sedangkan sisanya sebesar 64,8 persen (\%) dipengaruhi oleh variabel lain yang tidak dimasukan dalam penelitian.

Uji kelayakan model (uji F) bertujuan untuk menguji apakah semua variabel bebas berpengaruh terhadap variabel terikat dan untuk mengetahui model regresi yang digunakan dalam penelitian ini layak uji atau tidak. Hasil uji F dapat dilihat pada Tabel 5, sebagai berikut:

Tabel 5. Hasil Uji F

\begin{tabular}{lll}
\hline No & Keterangan & Nilai \\
\hline 1 & F hitung & 7,150 \\
2 & Sig. F hitung & 0,01 \\
\hline
\end{tabular}

Sumber: Data Penelitian, 2020

Berdasarkan Tabel 5, menunjukan bahwa nilai $\mathrm{F}$ diperoleh sebesar 7,150 dengan tingkat signifikansi 0,01. Karena tingkat signifikansi 0,01 lebih kecil dari 0,05 ini berarti bahwa seluruh variabel yang digunakan dalam penelitian ini layak digunakan.

Uji hipotesis menggunakan uji t menunjukan seberapa jauh pengaruh satu variabel indenpenden secara individual untuk menerangkan variasi variabel dependen. Hasil uji hipotesis dapat dilihat pada Tabel 6, sebagai berikut:

Tabel 6. Hasil Uji t

\begin{tabular}{llll}
\hline No & Variabel & $\mathrm{t}$ & Sig. \\
\hline 1 & Tingkat Pendidikan (X1) & 1,856 & 0,005 \\
2 & Pengalaman Kerja (X2) & 2,690 & 0,004 \\
3 & Gaya Kepemimpinan (X3) & 3,256 & 0,003 \\
\hline
\end{tabular}

Berdasarkan hasil uji statistik $\mathrm{t}$ dengan membandingkan nilai t-hitung dengan t-tabel taraf kesalahan $5 \%$ menunjukan variabel tingkat pendidikan $\left(X_{1}\right)$ dengan nilai signifikansi 0,005 $<0,05$ dan mempunyai nilai t-hitung adalah 1,856 $>$ nilai t-tabel 1,696, maka dapat disimpulkan bahwa tingkat pendidikan berpengaruh positif pada efektivitas sistem pengendalian internal Bank $X$ Denpasar.

Hasil penelitian ini sejalan dengan penelitian Mirawati (2014) yang menyatakan bahwa tingkat pendidikan berpengaruh positif terhadap efektivitas sistem pengendalian internal pada perusahaan tekstil di Sukoharjo. Hal ini juga sesuai dengan hasil yang dicapai oleh Bhuaneswari \& Damayanthi (2018) menyatakan bahwa tingkat pendidikan berpengaruh positif terhadap efektivitas sistem pengendalian internal LPD di Kota Denpasar.

Penelitian ini mendukung teori stewardship dimana satuan pengawai atau karyawan sistem pengendalian internal sebagai steward yang bertugas membantu pimpinan di masing-masing instansi perbankan dalam hal pengawasan sistem pengendalian internal penting untuk memiliki tingkat pendidikan yang tinggi guna meningkatkan kemampuan dalam melakukan pengawasan sebagai upaya meningkatkan efektivitas sistem pengendalian internal. Hal ini dapat dilihat dari sebagian besar pegawai atau karyawan satuan pengawas sistem pengendalian internal yang sudah bergelar (S1) sehingga diharapkan mereka mampu lebih cepat 
mempelajari hal-hal baru berkaitan dengan tugas mereka melakukan pengawasan sistem pengendalian internal, para pegawai juga sering mengikuti seminar dan pelatihan yang berhubungan dengan sistem pengendalian internal untuk menambah wawasan dan mengetahui tingkat perkembangan standar yang ada.

Berdasarkan hasil uji statistik $\mathrm{t}$ dengan membandingkan nilai $\mathrm{t}$-hitung dengan $\mathrm{t}$-tabel pada taraf kesalahan $5 \%$ menunjukan variabel pengalaman kerja $\left(X_{2}\right)$ dengan nilai signifikan 0,004 <0,05 dan mempunyai nilai t-hitung adalah 2,690 $>$ nilai t-tabel 1,696 maka dapat disimpulkan bahwa pengalaman kerja berpengaruh positif pada efektivitas sistem pengendalian internal Bank $X$ Denpasar.

Hasil penelitian ini sejalan dengan penelitian Dianawati \& Ramantha (2013) yang menyatakan pengalaman kerja auditor internal berpengaruh terhadap efektivitas sistem pengendalian internal. Hal ini karena pengalaman kerja auditor internal merupakan suatu proses pembelajaran dan pertambahan potensi bertingkah laku baik dari pendidikan formal maupun pendidikan non formal atau bisa diartikan suatu proses yang membawa seseorang kepada suatu pola tingkah yang lebih tinggi.

Hasil penelitian ini mendukung teori stewardship, dimana satuan pengawas pengedalian internal sebagai steward yang bertugas membantu pimpinan di masing-masing instansi dalam hal pengawasan internal penting untuk memiliki pengalaman yang memadai. Hal ini sudah terlihat dari Bank $X$ yang menjadi sampel dalam penelitian, karena satuan pengawai atau karyawan sistem pengendalian tersebut memiliki rata-rata pengalaman kerja di atas 2 tahun. Semakin lama pengalaman kerja pegawai atau karyawan satuan pengawas sistem pengendalian internal, maka pegawai atau karyawan akan lebih memahami dan menguasai suatu keterampilan dalam bidang yang ditekuni dan dapat menghasilkan laporan hasil pengawasan yang lebih baik.

Berdasarkan hasil uji statistik $\mathrm{t}$ dengan membandingkan nilai t-hitung dengan $t$-tabel pada taraf kesalahan $5 \%$, menunjukan variabel gaya kepemimpinan $\left(X_{3}\right)$ dengan nilai signifikansi 0,003 $<0,05$ dan mempunyai nilai thitung adalah 3,256 > nilai t-tabel 1,696, maka dapat disimpulkan gaya kepemimpinan berpengaruh positif pada efektivitas sistem pengendalian internal Bank X Denpasar.

Hasil penelitian ini sejalan dengan penelitian Schaefer \& Savulescu (2014) yang menyatakan bahwa pemimpin mempunyai peran yang cukup besar dalam memantau pelaksanaan kegiatan dalam suatu organisasi dan efektivitas sistem pengendalian internal dapat melemah ketika terjadi inkonsistensi dalam melakukan bimbingan oleh seorang pemimpin. Berkaitan dengan gaya kepemimpinan, Penelitian yang dilakukan Hayati (2015) menemukan dan mengevaluasi bahwa perlunya untuk mengoptimalkan pemantauan dalam rangka pengawasan. Gaya kepemimpinan yang buruk akan mempengaruhi kepuasan kerja karyawan, sehingga menyebabkan karyawan atau pegawai cenderung merugikan perusahaannya. Tindakan korupsi bisa saja dilakukan karena kesalahan pemimpin dalam menempatkan staf di unit-unit kerja. Akibatnya, ruang untuk terjadinya tindakan korupsi terbuka lebar. 


\section{SIMPULAN}

Penelitian yang dilakukan dapat memberikan kontribusi bagi perkembangan ilmu pengetahuan maupun referensi. Hal ini karena tingkat pendidikan, pengalaman kerja dan gaya kepemimpinan mampu meningkatkan sistem pengendalian internal pada Bank X Denpasar. Berdasarkan hasil penelitian ini maka perlu diperhatikan bahwa dalam meningkatkan efektivitas sistem pengendalian internal Bank X Denpasar, pimpinan instansi Bank X Denpasar harus memperhatikan tingkat pendidikan, pengalaman kerja dan gaya kepemimpinan.

\section{REFERENSI}

Abiola, I. (2013). Internal Control System on Detection: Nigeria Experience Ladoke Akintola University of Technology Ladoke Akintola University of Technology. Journal of Accounting and Finance, 13(5), 137-149.

Afifah, N. N., \& Azwari, P. C. (2015). The Effect Of The Implementation Of Government Internal Control System (GICS) On The Quality Of Financial Reporting Of The Local Government and Its Impact On The Principles Of Good Governance: A Research In District, City and Procincial Government In Sout.

Akadita, P. (2010). Pengaruh Komposisi Badan Pengawas, Lingkup Operasional, Pertumbuhan Kredit, Komposisi Pendanaan dan Tingkat Suku Bunga pada Profitabilitas LPD di Kecamatan Denpasar Selatan. Universitas Udayana.

Apsari, N. N. S., \& Gayatri. (2018). Pengaruh Independensi, Gaya Kepemimpinan, Komitmen Organisasi, Pegalaman Kerja, dan Pemahaman Good Governance pada Kinerja Auditor. E-Jurnal Akuntansi Univeristas Udayana, 24(1), 282-310.

Azzali, S., \& Mazza, T. (2018). The Internal Audit Effectiveness Evaluated with On Organizational, Process and Relationship Prespective. International Journal of Business and Management, 13(6), 238-254. https:// doi.org/10.5539/ijbm.v13n6p238

Bhuaneswari, A. A. A. M., \& Damayanthi, I. G. A. E. (2018). Pengaruh Karakteristik Pengawas Internal terhadap Efektivitas Pengendalian Internal Lembaga Perkreditan Desa di Kota Denpasar. E-Journal Akuntansi Universitas Udayana, 22(3), 1800-1825. https://doi.org/https://doi.o rg/10.24843/EJA.2018.v22.i03.p0 6

Dianawati, N. M. D., \& Ramantha, W. (2013). Pengaruh Indepedensi, Keahlian Profesional dan Pengalaman Kerja Auditor Internal Terhadap Efektivitas Struktur Pengendalian Internal Bank Pekreditan Rakyat di Kabupaten Gianyar. E- Jurnal Fakultas Ekonomi Dan Bisnis Universitas Udayana, 4(3), 430450.

Ekayanti, W., Sujana, E., \& Wahyuni, M. A. (2017). Pengaruh Budaya Organisasi, Gaya Kepemimpinan, dan Pengalaman Kerja Terhadap Efektivitas Sistem Pengendalian Intern Pada Lembaga Perkreditan Desa (Lpd) Se-Kecamatan Payangan Kabupaten Gianyar. E-Journal S1 Ak Universitas Pendidikan Ganesha, 1(3).

Hayati. (2015). Evaluasi Pelaksanaan Sistem Pengendalian Internal Studi Pada Kantor Kementerian Agama Kabupaten Klaten. Universitas Gajah Mada.

Indriasih, D., \& Koeswayo, P. (2014). The Effect of Government Apparatus Competence and Effectiveness of Government Internal Control Toward The 
Financial Reporting and is Impact on The Performance Accountability in Local Government. South East Asian Journal Contemporary Buisness, Economics and Law, 5(1).

Irafah, S., Sari, E. N., \& Muhyarsyah, M. (2019). The Effect Of Competence Of Human Resources and The Internal Audit Role Of The Quality Of Financial Statements. International Journal of Economics and Business, 7(8).

Jones, M. J. (2008). Internal Control, Accountability and Corporate Government Medieval Britain Compared. Accounting Auditing and Accountability Journal, 21(7), 1052-1075.

Kibtiyah, M., Wirakusuma, M. G., \& Sari, M. M. R. (2017). Pengaruh Kompetensi, Budaya Organisasi, dan Gaya Kepemimpinan pada Efektivitas Sistem Pengendalian Internal Pengadaan Barang/Jasa Pemerintah. E-Jurnal Ekonomi Dan Bisnis Universitas Udayana, 6(5).

Mirawati, E. (2014). Pengaruh Pendidikan, Pengalaman dan Pelatihan Kerja Terhadap Efektivitas Sistem Pengendalian Intern. Universitas Muhammadiyah Surakarta.

Mulihartini, N. K., \& Muliartha, K. (2016). Pengalaman Kerja sebagai Pemoderasi Pengaruh Tingkat Pendidikan pada Efektivitas Sistem Pengendalian Internal. E- Jurnal Fakultas Ekonomi Dan Bisnis Universitas Udayana, 14(3), 1951-1977.

Salehi, T. (2016). Investigation Factors Affecting The Effectiveness of Internal Auditors in The Company: Review of European Studies. Review of European Studies, 8(2), 224-235.

Schaefer, G. O., \& Savulescu, J. (2014). The Ethics of Producing In Vitro Meat. Journal of Applied Philosophy. https://doi.org/https:/ / doi.org/10.1111/japp.12056

Soimah, S. (2014). Pengaruh Kapasitas Sumber Daya Manusia, Pemanfaatan teknologi Informasi, dan Sistem Pengendalian Intern Pemerintah terhadap Kualitas Laporan Keuangan Pemerintah Daerah Kabupaten Bengkulu Utara. Universitas Bengkulu.

Trijoko, P. (1980). Ilmu Budaya Dasar. Jakarta: Renika.

Tunji, S. S. (2013). Effective Internal Control System as Antidote for Distress in The Banking Industry in Nigeria. Journal of Economics and International Buisness Research, 1(3), 1-15.

Wambarika, I. G. A. C. S. A., \& Ramantha, I. W. (2017). Pengaruh Kompetensi Pada Penerapan Perlakuan Akuntansi Aset Bersejarah. E-Jurnal Akuntansi Universitas Udayana, 19(3), 2319-2347.

Wardani, R. N. (2014). Pengaruh Tingkat Pendidikan, Pengalaman Kerja, dan Pengendalian Internal terhadap Kualitas laporan Keuangan pada Kantor Kementerian Agama Kota Makasar. Universitas Islam Negeri (UIN) Alaudin Makasar.

Warren, Fees, \& Reeve. (2005). Pengantar Akuntansi (Jakarta). Penerbit Salemba Empat.

Wicaksono, W. C. (2013). Faktor-faktor yang Mempengaruhi Efektivitas Pengendalian intern di Sektor Pemerintahan (Persepsi Pegawai pada Dinas-dinas Kota Semarang). Universitas Negeri Semarang.

Wijaya, W. A., Arifati, R., \& Suprijanto, A. (2016). Analisis Pengaruh Independensi, Motivasi, Pengalaman Kerja, Profesionalisme, Dan Gaya Kepemimpinan Terhadap Efektivitas Penerapan Sistem Pengendalian Intern (Studi Empiris Pada Auditor Internal Yang Bekerja Di Perusahaan Pembiayaan Se- 
Kabupaten Kudus). Journal Of Accounting, 2(2).

Zahara, G., \& Silviana. (2015). The Influence of Competence Local Government Agencies and The Implementation Government of Internal Control System Toward The Quality of Local Government Financial Statement. Research Journal of Finance and Accounting, 6(11). 